\title{
Migraine and menstrual cycle synchrony in females: is there a relationship? Case report*
}

\author{
Migrânea e sincronização de ciclo menstrual em mulheres: existe uma relação? Relato de caso
}

Karen dos Santos Ferreira', Luiza Previdelli Bolinelli', Lígia Cristina Pagotto

${ }^{*}$ Received from School of Medicine, University Center Barão de Mauá of Ribeirão Preto, Ribeirão Preto, SP, Brazil.

DOI 10.5935/1806-0013.20150030

\section{ABSTRACT}

BACKGROUND AND OBJECTIVES: Migraine is a highly prevalent disorder among adult females, being that very often these patients have crises during the menstrual cycle. On the other hand, some studies have described menstrual cycle synchrony in females living together. No study has described whether there would also be migraine crisis synchrony among these females. This study aimed at reporting the case of a patient with migraine episodes synchronized with the menstrual cycle of her companion, discussing possible involved triggering factors.

CASE REPORT: Female patient, 50 years old, menopausal for at least one year, with history of migraine without aura according to International Headache Society's criteria, with typically migraine headache crises during her companion's menstrual cycle. Patient was evaluated for 3 months by the pain diary, including frequency of headache crises, intensity of crises, drug doses and triggering factors for crises, in addition to follicle exfoliating hormone and estradiol dosing in different periods of the month. Patient had headache crises during her companion's menstrual cycle with no evidence of other associated factors (diet, sleep deprivation, stress). Patient's level of stimulating follicle hormone varied throughout the month, according to companion's menstrual cycle.

CONCLUSION: There is no consensus with regard to menstrual cycle synchrony among females. However, we believe that this report could be a step further for the development of further studies on such a complex subject.

Keywords: Headache, Menstrual cycle, Migraine disorders.

1. School of Medicine, University Center Barăo de Mauá of Ribeirão Preto, Ribeirăo Preto, SP, Brazil.

Submitted in May 01, 2015

Accepted for publication in May 29, 2015.

Conflict of interests: none - Sponsoring sources: none.

Correspondence to:

Karen dos Santos Ferreira

Rua Ramos de Azevedo, 423 - Jardim Paulista

14090-180 Ribeirão Preto, SP, Brasil.

E-mail: karenferreira@usp.br

(C) Sociedade Brasileira para o Estudo da Dor

\section{RESUMO}

JUSTIFICATIVA E OBJETIVOS: A migrânea é uma desordem de alta prevalência em mulheres adultas, sendo quecom frequência essas pacientes apresentam crises durante o período menstrual. Por outro lado, alguns estudos descreveram sincronicidade de ciclos menstruais em mulheres que residem juntas. Nenhum estudo descreveu se haveria também uma sincronicidade das crises de migrânea entre essas mulheres. $\mathrm{O}$ objetivo deste estudo foi relatar um caso de uma paciente que apresentava episódios de migrânea sincronizados com a menstruação de sua companheira, discutindo os possíveis fatores desencadeantes envolvidos.

RELATO DO CASO: Paciente de 50 anos, em menopausa há mais de um ano, com antecedente de migrânea sem aura de acordo com os critérios da InternationalHeadacheSociety, apresentando crises de cefaleia tipicamente migranosas durante o ciclo menstrual de sua companheira. Foi avaliada por 3 meses por meio de diário de dor, incluindo a frequência de crises de cefaleia, intensidade das crises, doses de fármacos utilizados e fatores desencadeantes de crises, além de dosagem de hormônio folículo esfoliante e estradiol em diferentes períodos do mês. A paciente apresentou crises de cefaleia durante o período menstrual da companheira, sem evidência de outros fatores associados (alimentação, privação de sono, estresse). Apresentou também níveis de hormônio folículoestimulante que variavam durante o mês, de acordo com o ciclo menstrual da companheira.

CONCLUSÃO: Não há um consenso com relação à sincronização de ciclos menstruais em mulheres. Entretanto, acredita-se que este relato poderia ser um passo para o desenvolvimento de estudos mais elaborados sobre um assunto táo complexo.

Descritores: Cefaleia, Menstruação, Transtornos de enxaqueca.

\section{INTRODUCTION}

Migraine is currently one of the most frequent and disabling headaches. It is a disorder affecting one out of five females and one out of 13 males in reproductive age. During childhood, boys and girls are equally affected. In puberty, the incidence of migraine without aura increases among females, being menstruation one of the most important risk factors for migraine without aura, and the post-menopausal period corresponds to decreased migraine crises ${ }^{1,2}$.

The World Health Organization (WHO) recognizes migraine as a disease causing major disability and loss of qual- 
ity of life (QL). Moderate to severe migraine is approximately twice more frequent in females as compared to males, decreasing their productivity at school, work, home and social activities ${ }^{3}$.

Approximately 50 to $60 \%$ of migraine females have menstrual headache. The risk of migraine without aura increases during peri-menstrual days, starting two days before menstruation and continuing to up to three days after the first menstrual day. Females are $70 \%$ more predisposed to pain in the two days preceding menstruation than in the other days of the cycle, and $50 \%$ are further predisposed in the first menstrual day ${ }^{4,5}$. Menstrual migraine pathophysiology is associated to decreased estrogen few days before menstruation. Increased prostaglandins are also implied in the triggering of crises ${ }^{4,5}$.

The International Headache Society (IHS) recognizes two types of menstrual migraine ${ }^{6}$ :

- Menstrual-related migraine: migraine without aura regularly occurring between two days before and three days after the first menstrual cycle day, with additional crises with and without aura in other cycle periods, at least in two out of three menstrual cycles;

- Pure menstrual migraine: occurring just between two days before and three days after the first menstrual cycle day.

Menstrual synchrony is the term to define menstrual cycles in nearby periods in females living in proximity. This phenomenon occurs in some animals with biological evolutionary mechanism. In humans, McClintock was the first researcher to describe this process. Her study has considered $135 \mathrm{fe}$ males, aged between 17 and 22 years, living together in a college environment. Females were paired in groups by affinity and higher menstrual cycle synchrony was found in these groups ${ }^{7}$.

Graham \& McGrew tried to replicate this study in a college environment and have found synchrony among close friends, but not among room neighbors. Synchrony mechanism remained unknown, with hypothesis related to pheromones or emotional aspects of females ${ }^{8}$. Other investigators developed more recent studies, which have not found synchrony among menstrual cycles of females living in the same environment ${ }^{9-11}$. Although frequent during the menstrual cycle, no study evaluating menstrual synchrony in females living together in college environment has described the presence of menstrual migraine among them.

This study aimed at reporting the case of a patient with migraine episodes during the menstrual cycle of her female companion by analyzing possible involved factors (menstruation, stress, diet, sleep deprivation).

\section{CASE REPORT}

This study was carried out in the School of Medicine, University Center Barão de Mauá, Ribeirão Preto, São Paulo, as from a patient of a Neurology professor. Female patient, 50 years old, in menopause for more than one year, with history of migraine without aura according to International Head- ache Society criteria. She reported crises of pulsatile, unilateral, severe headache, with typically migranous nausea, which were described during the menstrual cycle of her companion. She lived with female companion of 36 years of age, who have regular menstrual cycles every 28 days. There were no clinical comorbidities or psychiatric disorders. Patient was not under regular drugs, except for simple analgesics. At general physical and neurological evaluation no changes were found to indicate diagnosis of secondary headache. So, the diagnosis of migraine without aura was maintained.

During the first visit, clinical history and detailed general physical and neurological evaluation were obtained. Patient received a pain diary to be filled during the next 3 months, after being oriented about the correct filling of data. Serum hormone dosage was requested to be collected the next month. In every studied "menstrual" period, we have evaluated pain intensity, pain quality, location, associated symptoms (photophobia, phonophobia, osmophobia, nausea), analgesic drugs and doses used, triggering factors, such as diet, sleep deprivation, stress and companion's menstruation days. In addition, DSM-5 criteria for diagnosis of Major Depressive Disorder and Generalized Anxiety Disorder ${ }^{12}$ were applied. We have also requested follicle-stimulating hormone (FSH) and estradiol plasma dosage in the first and fourth menstrual cycle days of her companion.

In the second visit, scheduled for 3 months later, pain diary items and tests results were evaluated with the patient. As result, patient had headache crises during her companion's menstrual cycle for three consecutive months, described in the pain diary. According to the diary, there has been no evidence of other associated factors (diet, sleep deprivation, stress). These pain crises were medicated with naproxen (550 $\mathrm{mg}$ ) every $12 \mathrm{~h}$, with partial improvement. Patient had FSH level of $73.64 \mathrm{MIU} / \mathrm{mL}$ in the first cycle day and of 80.05 $\mathrm{mIU} / \mathrm{mL}$ in the $14^{\text {th }}$ menstrual cycle of her companion. Plasma estradiol levels remained unchanged $(<10 \mathrm{pg} / \mathrm{mL}$ in both measurements). Preventive drug was started. She was treated with valproic acid $(500 \mathrm{mg})$ every $12 \mathrm{~h}$, with major improvement in headache crises on subsequent months.

\section{DISCUSSION}

This case report describes a menopausal patient for more than one year, with previous diagnosis of migraine without aura, having in the last year headache crises reported during her companion's menstrual period. Which would be the explanation for headache crises in this age bracket? A coincidence of manifestation? Would there be the implication of associated emotional factors? Would there be some hormonal modulation triggering such crises?

First of all, clinical migraine course is variable during menopause, with a trend to fewer crises in this period. So, for this patient, it was expected that pain crises would decrease for this age bracket. Normal general physical and neurological evaluations also rule out secondary diagnoses for this headache ${ }^{4}$. On the other hand, different factors, such as diet, sleep deprivation 
and stress could trigger crises in migraine patients. These factors were discarded after adequate filling of the pain diary for three consecutive months. Finally, Diagnostic and Statistical Manual of Mental Disorders (DSM-5) criteria were applied to diagnose patient's Major Depressive Disorder and Generalized Anxiety Disorder, with negative results for such comorbidities ${ }^{13}$.

So, would there be hormonal modulation aspects involved with this manifestation? Ovarian hormones have major influence on females' central nervous system. They modulate the number of neurotransmitting systems important for the pathogenesis of several neurological diseases. Especially migraine seems to be strongly affected by ovarian hormones. During the menstrual cycle, predominant estrogen effect seems to be facilitation of glutamatergic and serotoninergic systems. On the other hand, primary progesterone effect seems to be gabaergic systems activation, as well as modulation of estrogen actions on the central nervous system. So, estrogen and progesterone may be involved with migraine pathophysiology ${ }^{14}$.

Reproductive events during females' lives are closely related to their migraine crises. Decreased estrogen and its effects on the central nervous system are the primary mechanism responsible for symptoms during menopause, such as hot flashes and headaches. Several of the same altered neurotransmitter systems during menstrual migraine secondary to decreased estrogen may also be affected by menopause ${ }^{15}$.

But what would lead to possible synchrony among females? Pheromones are chemicals released by one individual to the environment which affect the physiology or behavior of other members of the same species. In other species, there are many types of pheromones which are independent of the ovarian function allowing the regulation of different neuroendocrine aspects. The existence of human pheromones was initially suggested by the demonstration that females living together could develop synchronized menstrual cycles under specific conditions ${ }^{16}$.

Odorless axillary compounds of females in the later follicular stage of their menstrual cycles, applied to a second group of females, have accelerated the LH pre-ovulation peak of this group, thus shortening their menstrual cycles. Axillary compounds of the same donors collected at the end of the menstrual cycle (ovulation) had opposite effect when applied to a second group of females: they have delayed the luteinizing hormone-outbreak of recipients and have prolonged their menstrual cycles $^{16}$.

Specifically with regard to lesbian couples, results are controver- sial. Some studies describe menstrual cycles synchrony related to involved hormonal and social factors (proximity of contact, social activities performed in common), supporting menstrual cycles synchrony with no more than two days difference, while other studies have not confirmed such findings ${ }^{17,18}$.

In our case, in addition to clinical symptoms description, we have found a slight FSH variation in the beginning and middle of the menstrual cycle, simulating variation of a physiological menstrual cycle, that is, with pre-ovulation FSH peak. Although discreet, such findings in a post-menopausal female could indicate some hormonal change occurring during this period.

To conclude, it is known that results described herein are controversial and that there is no consensus with regard to menstrual cycle synchrony among females. However, since there is no description in the literature about migraine crises synchrony in patients living together, we believe that this report could be a step further for the development of more elegant studies about such a complex subject.

\section{REFERENCES}

1. Rasmussen BK. Epidemiology of headache. Cephalalgia. 2001;21(7):774-7.

2. Stewert WF, Roy J, Lipton RB. Migraine prevalence, socioeconomic status, and social causation. Neurology. 2013;81(11):948-55

3. Becker WJ, Gladstone JP, Aube M. Migraine prevalence, diagnosis, and disability. Can J Neurol Sci. 2007;34(4):3-9.

4. MacGregor EA. Progress in the pharmacotherapy of menstrual migraine. Clin Med Insights Therapeutics. 2011;3:245-73.

5. MacGregor EA. Migraine headache in perimenopausal and menopausal women. Curr Pain Headache Rep. 2009;13:399-403.

6. The International Classification of Headache Disorders $3^{\text {nd }}$ ed. Cephalalgia. 2013;33(9):644-58.

7. McClintock MK. Menstrual synchrony and suppression. Nature. 1971;229(5282):244-5.

8. Graham CA, McGrew WC. Menstrual synchrony in female undergraduates living on a coeducational campus. Psychoneuroendocrinology. 1980;5(3):245-52.

9. Wilson H, Kiefhaber S, Gravel V. Two studies of menstrual synchrony: negative results. Psychoneuroendocrinology. 1991;16(4):353-9.

10. Trevathan WR, Burleson MH, Gregory WL. No evidence for menstrual synchrony in lesbian couples. Psychoneuroendocrinology. 1993;18(5-6):425-35.

11. Ziomkiewicz A. Menstrual synchrony: fact or artifact? Human Nature. 2006;17(4):419-32.

12. American Psychiatry Association. Diagnostic and Statistical Manual of Mental Disorders - DSM-5. $5^{\text {th }}$ ed. Washington: American Psychiatric Association, 2013.

13. Breslau N. Comorbidity of migraine and depression: investigating potential etiology and prognosis. Neurology. 2003;60(8):1308-12.

14. Martin VT, Behbehani M. Ovarian hormones and migraine headache: understanding mechanisms and pathogenesis--Part 1. Headache. 2006;46(1):3-23.

15. Dhillon KS, Singh J, Lyall JS. A new horizon into the phatobiology, etiology and theatment of migraine. Med Hypotheses. 2011;77(1):147-51.

16. Stern K, McClintock MK. Regulation of ovulation by human pherormones. Nature 1998;392(6672):177-9

17. Trevathan WR, Burleson MH, Gregory WL. No evidence for menstrual synchrony in lesbian couples. Psychoneuroendocrinology. 1993;18(5):425-35.

18. Weller A, Weller L. Menstrual synchrony in female couples. Psychoneuroendocrinology. 1992;17(2-3):171-7. 